\title{
Gambaran Komplikasi Kehamilan dengan Penyakit Jantung di RSUD Arifin Achmad Provinsi Riau Periode 2013-2017
}

\author{
Muhammad Arif Syafei ${ }^{1}$, Donel Suhaimi², Irwan $^{3}$
}

\begin{abstract}
Heart disease is the major non-obstetric cause of morbidity and mortality in pregnancy Several studies showed that pregnancy with heart diseases are related to maternal and perinatal complications such as mortality, heart failure, arrhytmias, pulmonary oedema, low birth weight, and prematurity. The aim of this study is to know the incidence, characteristic, and complications of pregnancy with heart disease. This study was using descriptive retrospective design with total sampling technique. The sources of data were medical records of patients in January 2013 - December 2017 with number of sample is 37 patients. Cardiac complications was found in $19(57,6 \%)$ cases that was composed of arrhytmias (24,2\%), prematurity (21,2\%), pulmonary oedema and low birth weight both 15,2\%, and heart failure (9,1\%).
\end{abstract}

Keywords : pregnancy, heart disease, complication

Dewasa ini dengan semakin berkembangnya modalitas diagnosis dan terapi penyakit jantung semakin banyak wanita dengan penyakit jantung yang dapat mencapai usia dewasa dengan status fungsional jantung yang baik. Oleh karena itu, saat ini kehamilan menjadi hal yang memungkinkan bagi wanita yang menderita penyakit jantung. ${ }^{1}$ Kehamilan sendiri menyebabkan berbagai perubahan pada sistem kardiovaskular, yang mana pada jantung yang sakit hal ini terkadang tidak dapat ditoleransi dan berpotensi meningkatkan risiko mortalitas maupun morbiditas ibu dan bayi. ${ }^{2}$

Penyakit jantung merupakan penyebab nonobstetrik utama kematian maternal di seluruh dunia. ${ }^{2}$ Penyebab nonobstetrik yang termasuk di dalamnya penyakit jantung berkontribusi sebesar $27,5 \%$ dari seluruh kematian maternal. ${ }^{3}$ Sekitar 0,2 $-4 \%$ kehamilan disertai dengan penyakit jantung di Eropa. ${ }^{4}$ Di Inggris dan Irlandia, penyakit jantung

\footnotetext{
* Penulis untuk korespondensi : Email: arifs21m@gmail.com

1 Program Studi Kedokteran Fakultas Kedokteran Universitas Riau Pekanbaru, Indonesia

2 KJFD.KSM Obstetri-Ginekologi Fakultas Kedokteran Universitas Riau/ RSUD Arifin Achmad Provinsi Riau, Indonesia

${ }^{3}$ KJFD/KSM Jantung dan Kedokteran Vaskuler Fakultas Kedokteran Universitas Riau/ RSUD Arifin Achmad Provinsi Riau, Indonesia
}

merupakan penyebab non obstetrik utama kematian maternal, dimana terdapat 2,34 kematian per 100.000 kehamilan pada ibu dengan penyakit jantung. ${ }^{5}$

Menurut data Kementerian Kesehatan RI pada tahun 2010-2013 terdapat 359 kematian ibu per 100.000 kehamilan di Indonesia, dimana penyebab tertinggi kematian ibu adalah penyebab non obstetrik yang mencakup di dalamnya penyakit jantung (34,95\%). ${ }^{6}$ Di Provinsi Riau pada tahun 2015 terdapat 109 kasus kematian ibu, yang mana sebesar $52 \%$ diantaranya disebabkan oleh penyebab non bobstetrik. $^{7}$

Kehamilan dengan penyakit jantung berhubungan dengan peningkatan risiko morbiditas ibu dan bayi, yang mana besarnya risiko tergantung dari jenis dan derajat keparahan penyakit jantung yang diderita. ${ }^{2}$ Hipertensi pulmonal dan stenosis katup mitral merupakan jenis penyakit jantung yang memiliki risiko tinggi untuk mengalami komplikasi dalam kehamilan. Morbiditas yang pernah dilaporkan terjadi pada ibu dengan penyakit jantung adalah gagal jantung $(6,5 \%)$, aritmia (3,2\%), dan edema paru $(2,4 \%))^{1,2}$ Penelitian oleh Siu et al. mengenai prognosis kehamilan pada 302 wanita dengan penyakit jantung didapatkan jumlah komplikasi neonatal sebesar $18 \%$. Persalinan preterm terjadi pada $15 \%$ kehamilan, IUGR sebanyak $4 \%$ kasus, 
Acute Respiratory Distress Syndrome (ARDS) sebanyak $2 \%$, dan kematian neonatal pada $3 \%$ kehamilan. ${ }^{8}$

Di Indonesia terdapat beberapa penelitian mengenai insidensi dan gambaran komplikasi penyakit jantung dalam kehamilan. Penelitian oleh Wiyati di RSUP Dr. Kariadi Semarang, terdapat 59 kasus kehamilan dengan penyakit jantung. Penyakit jantung terbanyak yaitu kelainan katup jantung (25 kasus). Komplikasi terbanyak yang ditemukan adalah gagal jantung. Sebagian besar bayi lahir hidup yaitu sebanyak 57 bayi ((90,3\%). ${ }^{9}$ Hasil penelitian Tanika di RSUD Arifin Achmad Provinsi Riau pada tahun 2014 - 2016, terdapat 24 kasus kehamilan dengan penyakit jantung. Usia terbanyak ibu hamil dengan penyakit jantung adalah dalam rentang usia 20-30 tahun, yaitu sebanyak 12 ibu hamil. Berdasarkan status paritas, primipara merupakan yang terbanyak, yaitu sebanyak $10 \mathrm{ibu}$ hamil. ${ }^{10}$

Berdasarkan uraian diatas, penulis tertarik melakukan penelitian untuk melihat bagaimana gambaran komplikasi kehamilan dengan penyakit jantung di RSUD Arifin Achmad Provinsi Riau pada tahun 2013 - 2017.

\section{METODE}

Penelitian ini menggunakan metode deskriptif retrospektif menggunakan data rekam medis pasien hamil dengan penyakit jantung yang ditangani di bagian Obstetri dan Ginekologi RSUD Arifin Achmad Provinsi Riau pada periode 1 Januari 2013 - 31 Desember 2017. Penelitian ini dilakukan pada bulan Desember 2018 - Maret 2019 di Instalasi Rekam Medis serta KSM Obstetri dan Ginekologi RSUD Arifin Achmad Provinsi Riau. Populasi penelitian ini adalah semua pasien hamil dengan penyakit jantung yang ditangani di bagian Obstetri dan Ginekologi RSUD Arifin Achmad Provinsi Riau pada periode 1 Januari 2013 - 31 Desember 2017. Sampel berjumlah 37 orang yang diambil dengan teknik total sampling. Data rekam medis yang diambil berupa jumlah pasien hamil dengan penyakit jantung, umur, riwayat menderita penyakit jantung, jumlah kunjungan antenatal, serta ada atau tidaknya komplikasi kehamilan dengan penyakit jantung yang meliputi kematian maternal, gagal jantung, aritmia, edema paru, kematian perinatal, bayi berat lahir rendah (BBLR), dan kelahiran prematur.

Pengumpulan data berupa variabel penelitian yang diperoleh dari data sekunder, yaitu rekam medis pasien hamil dengan penyakit jantung yang ditangani di bagian Obstetri dan Ginekologi RSUD Arifin Achmad Provinsi Riau pada tahun 2013-2017. Pengolahan data dilakukan secara manual dengan mencatat data rekam medis berdasarkan variabel yang dibutuhkan pada penelitian ini, kemudian data tersebut disajikan dalam bentuk tabel distribusi frekuensi dan narasi untuk digunakan dalam penarikan kesimpulan.

Penelitian ini telah lulus kaji etik oleh Unit Etika Penelitian Kedokteran dan Kesehatan Fakultas Kedokteran Universitas Riau dengan Nomor Surat 003/UN.19.5.1.1.8/UEPKK/2019.

\section{HASIL}

Insidensi kehamilan dengan penyakit jantung di RSUD Arifin Achmad Provinsi Riau pada tahun 2013 -2017 adalah 37 kasus (0,43\%) dari 8.685 persalinan pada periode tersebut. Terdapat 33 kasus yang memenuhi kriteria inklusi.

Tabel 1. Insidensi kehamilan dengan penyakit jantung di RSUD Arifin Achmad Provinsi Riau tahun 20132017

\begin{tabular}{cccc}
\hline Tahun & Jumlah persalinan & $\begin{array}{c}\text { Kehamilan dengan } \\
\text { penyakit jantung }\end{array}$ & Persentase (\%) \\
\hline 2013 & 3542 & 5 & 0,14 \\
2014 & 1680 & 11 & 0,65 \\
2015 & 1498 & 4 & 0,27 \\
2016 & 1087 & 6 & 0,55 \\
2017 & 878 & 7 & 0,80 \\
\hline Total & $\mathbf{8 6 8 5}$ & $\mathbf{3 3}$ & $\mathbf{0 , 3 8}$ \\
\hline
\end{tabular}


Tabel 2. Gambaran faktor risiko kehamilan dengan penyakit jantung di RSUD Arifin Achmad Provinsi Riau tahun 2013-2017

\begin{tabular}{lcc}
\hline $\begin{array}{c}\text { Faktor risiko kehamilan dengan } \\
\text { penyakit jantung }\end{array}$ & $\begin{array}{c}\text { Frekuensi } \\
(\mathrm{n}=33)\end{array}$ & Persentase (\%) \\
\hline Usia ibu & 1 & 3,0 \\
$\quad<20$ tahun & 24 & 72,7 \\
$20-35$ tahun & 8 & 24,2 \\
$>35$ tahun & & 63,6 \\
Riwayat penyakit jantung & 21 & 36,4 \\
$\quad$ Ya & 12 & 27,3 \\
Tidak & 9 & 72,7 \\
Jumlah kunjungan antenatal & 24 & \\
$\quad<4 \mathrm{x}$ & & \\
$=4 \mathrm{x}$ & &
\end{tabular}

Usia ibu paling banyak berkisar antara 20 - 35 tahun (72,7\%). Berdasarkan riwayat menderita penyakit jantung sebelumnya, terdapat sebanyak 21 kasus (63,6\%) ibu yang memiliki riwayat menderita penyakit jantung. Sebagian besar pasien melakukan kunjungan antenatal sebanyak 4 kali atau lebih (72,7\%). Gambaran faktor risiko kehamilan dengan penyakit jantung di RSUD Arifin Achmad Provinsi Riau pada tahun 2013 - 2017 dapat dilihat pada Tabel 2.

Frekuensi munculnya komplikasi pada kehamilan dengan penyakit jantung di RSUD Arifin Achmad Provinsi Riau pada tahun 2013 - 2017 adalah sebanyak 19 kasus (57,6\%).

Tabel 3. Frekuensi komplikasi kehamilan dengan penyakit jantung di RSUD Arifin Achmad Provinsi Riau tahun 2013-2017

\begin{tabular}{cccc}
\hline Tahun & $\begin{array}{c}\text { Kehamilan dengan } \\
\text { penyakit jantung }\end{array}$ & $\begin{array}{c}\text { Frekuensi komplikasi } \\
\text { kehamilan dengan } \\
\text { penyakit jantung }\end{array}$ & Persentase (\%) \\
\hline 2013 & 5 & 3 & 60,0 \\
2014 & 11 & 7 & 63,6 \\
2015 & 4 & 3 & 75,0 \\
2016 & 6 & 1 & 16,7 \\
2017 & 7 & 5 & 71,4 \\
\hline Total & $\mathbf{3 3}$ & $\mathbf{1 9}$ & $\mathbf{5 7 , 6}$ \\
\hline
\end{tabular}

Dalam penelitian ini tidak ditemukan komplikasi berupa kematian maternal. Terdapat sebanyak 3 kasus (9,1\%) yang disertai dengan komplikasi gagal jantung. Ada sebanyak 8 kasus (24,2\%) yang disertai dengan komplikasi aritmia. Ditemukan sebanyak 5 kasus (15,2\%) kehamilan dengan penyakit jantung yang disertai dengan komplikasi edema paru. Gambaran komplikasi kehamilan dengan penyakit jantung dapat dilihat pada Tabel 4 dan Tabel 5. 
Tabel 4. Gambaran komplikasi gagal jantung dan aritmia pada ibu hamil dengan penyakit jantung di RSUD Arifin Achmad Provinsi Riau tahun 2013-2017

\begin{tabular}{cccccc}
\hline Tahun & $\begin{array}{c}\text { Kehamilan } \\
\text { dengan penyakit } \\
\text { jantung }\end{array}$ & $\begin{array}{c}\text { Gagal } \\
\text { jantung }\end{array}$ & $\begin{array}{c}\text { Persentase } \\
\mathbf{( \% )}\end{array}$ & Aritmia & Persentase (\%) \\
\hline $\mathbf{2 0 1 3}$ & 5 & 0 & 0,0 & 0 & 0,0 \\
$\mathbf{2 0 1 4}$ & 11 & 3 & 27,3 & 5 & 45,5 \\
$\mathbf{2 0 1 5}$ & 4 & 0 & 0,0 & 0 & 0,0 \\
$\mathbf{2 0 1 6}$ & 6 & 0 & 0,0 & 1 & 16,7 \\
$\mathbf{2 0 1 7}$ & 7 & 0 & 0,0 & 2 & 28,6 \\
Total & $\mathbf{3 3}$ & $\mathbf{3}$ & $\mathbf{9 , 1}$ & $\mathbf{8}$ & $\mathbf{2 4 , 2}$ \\
\hline
\end{tabular}

Tabel 5. Gambaran komplikasi edema paru pada ibu hamil dengan penyakit jantung di RSUD Arifin Achmad Provinsi Riau tahun 2013-2017

\begin{tabular}{cccccc}
\hline Tahun & $\begin{array}{c}\text { Kehamilan dengan } \\
\text { penyakit jantung }\end{array}$ & $\begin{array}{c}\text { Edema } \\
\text { paru }\end{array}$ & $\begin{array}{c}\text { Persentase } \\
(\%)\end{array}$ & Tahun & $\begin{array}{c}\text { Kehamilan dengan penyc } \\
\text { jantung }\end{array}$ \\
\hline 2013 & 5 & 0 & 0,0 & 2013 & 5 \\
2014 & 11 & 2 & 18,2 & 2014 & 11 \\
2015 & 4 & 0 & 0,0 & 2015 & 4 \\
2016 & 6 & 0 & 0,0 & 2016 & 6 \\
2017 & 7 & 3 & 42,9 & 2017 & 7 \\
Total & $\mathbf{3 3}$ & $\mathbf{5}$ & $\mathbf{1 5 , 2}$ & Total & $\mathbf{3 3}$ \\
\hline
\end{tabular}

Dalam penelitian ini tidak ditemukan komplikasi berupa kematian perinatal pada bayi dari ibu dengan penyakit jantung di RSUD Arifin Achmad Provinsi Riau tahun 2013 - 2017. Terdapat 5 kasus (15,2\%) kehamilan dengan penyakit jantung yang disertai komplikasi BBLR. Ada sebanyak 7 kasus (21,2\%) bayi dari ibu dengan penyakit jantung lahir prematur. Gambaran komplikasi kehamilan dengan penyakit jantung pada bayi dari ibu dengan penyakit jantung dapat dilihat pada Tabel 6 dan Tabel 7.

Tabel 6. Gambaran komplikasi BBLR pada bayi dari ibu dengan penyakit jantung di RSUD Arifin Achmad Provinsi Riau tahun $2013-2017$

\begin{tabular}{cccccc}
\hline Tahun & $\begin{array}{c}\text { Kehamilan dengan } \\
\text { penyakit jantung }\end{array}$ & BBLR & $\begin{array}{c}\text { Persentase } \\
(\%)\end{array}$ & Tahun & $\begin{array}{c}\text { Kehamilan dengan penyakit } \\
\text { jantung }\end{array}$ \\
\hline 2013 & 5 & 2 & 40,0 & 2013 & 5 \\
2014 & 11 & 2 & 18,2 & 2014 & 11 \\
2015 & 4 & 0 & 0,0 & 2015 & 4 \\
2016 & 6 & 1 & 16,7 & 2016 & 6 \\
2017 & 7 & 0 & 0,0 & 2017 & 7 \\
Total & $\mathbf{3 3}$ & $\mathbf{5}$ & $\mathbf{1 5 , 2}$ & Total & $\mathbf{3 3}$ \\
\hline
\end{tabular}


Tabel 7. Gambaran komplikasi kelahiran prematur pada bayi dari ibu dengan penyakit jantung di RSUD Arifin Achmad Provinsi Riau tahun 2013 - 2017

\begin{tabular}{cccc}
\hline Tahun & $\begin{array}{c}\text { Kehamilan dengan } \\
\text { penyakit jantung }\end{array}$ & Kelahiran prematur & Persentase (\%) \\
\hline 2013 & 5 & 2 & 40,0 \\
2014 & 11 & 2 & 18,2 \\
2015 & 4 & 2 & 50,0 \\
2016 & 6 & 0 & 0,0 \\
2017 & 7 & 1 & 14,3 \\
\hline Total & $\mathbf{3 3}$ & $\mathbf{7}$ & $\mathbf{2 1 , 2}$ \\
\hline
\end{tabular}

\section{PEMBAHASAN}

\section{Insidensi kehamilan dengan penyakit jantung}

Berdasarkan penelitian yang telah dilakukan, terdapat 8.685 persalinan di RSUD Arifin Achmad Provinsi Riau pada tahun 2013 - 2017. Insidensi kehamilan dengan penyakit jantung adalah sebanyak 37 kasus (0,43\%). Sebanyak 33 kasus diantaranya memenuhi kriteria inklusi penelitian. Insidensi kehamilan dengan penyakit jantung dalam penelitian ini lebih rendah jika dibandingkan dengan penelitian yang dilakukan oleh Wiyati di RSUP dr. Kariadi Semarang, dimana terdapat 109 kasus kehamilan dengan penyakit jantung dari 11.199 persalinan $(0,97 \%)^{9}$

Hasil penelitian ini sesuai dengan kepustakaan yang menyatakan bahwa tedapat $0,2-0,4 \%$ kehamilan dengan penyakit jantung secara global. ${ }^{2}$ Penelitian oleh Pandey et al di India menunjukkan bahwa terdapat sebanyak $0,8 \%$ kehamilan dengan penyakit jantung. ${ }^{11}$ Hasil penelitian Owens et al di Amerika Serikat terdapat sebanyak $(0,2 \%)$ wanita hamil dengan penyakit jantung. ${ }^{12}$ Variasi insidensi kehamilan dengan penyakit jantung di berbagai negara terkait dengan adanya perbedaan status sosial ekonomi, tingkat pengetahuan, kemajuan metode diagnostik, dan metode pemilihan sampel yang berbeda. ${ }^{13}$

\section{Gambaran faktor risiko kehamilan dengan penyakit jantung}

Berdasarkan hasil penelitian didapatkan bahwa karakteristik usia pasien hamil dengan penyakit jantung yang terbanyak adalah dalam rentang usia reproduktif yaitu 20-35 tahun sebanyak 24 ibu hamil (72,7\%). Usia termuda ibu hamil dengan penyakit jantung adalah 18 tahun dan usia tertua adalah 46 tahun. Rata-rata usia ibu hamil dengan penyakit jantung adalah 30,3 tahun.

Hasil penelitian ini sama dengan penelitian oleh Wiyati di Semarang, yang mana kelompok usia terbanyak ibu hamil dengan penyakit jantung adalah dalam rentang usia 20-35 tahun sebanyak 78\%. ${ }^{9}$ Penelitian oleh Thanajiprapa di Thailand juga mendapatkan hasil mayoritas $(78,8 \%)$ ibu hamil dengan penyakit jantung adalah dalam rentang usia 20-34 tahun. ${ }^{14}$

Usia yang ideal bagi seorang wanita untuk menjalani kehamilan adalah dalam rentang usia 2035 tahun. Kehamilan dalam usia remaja berhubungan dengan imaturitas organ reproduksi, kurangnya pengetahuan mengenai kesehatan reproduksi, serta kurangnya kesadaran untuk melakukan kunjungan antenatal secara teratur. Selain itu, masa remaja yang masih memungkinkan tumbuh kembang ibu menyebabkan nutrisi yang masuk tidak disalurkan secara adekuat kepada janin karena nutrisi juga dibagi ke sirkulasi ibu untuk menunjang tumbuh kembang ibu. ${ }^{13}$ Adapun kehamilan pada usia lanjut berisiko baik bagi ibu maupun janin karena pada usia yang lebih tua terjadi penurunan fungsi berbagai sistem organ seperti sistem reproduksi dan sistem kardiovaskular. Salah satu dampaknya adalah plasentasi yang tidak adekuat sehingga suplai nutrisi untuk janin tidak mencukupi dan menyebabkan tumbuh kembang janin yang tidak adekuat. ${ }^{12,13}$

\section{Riwayat penyakit jantung}

Berdasarkan riwayat penyakit jantung sebelum kehamilan, terdapat 21 ibu $(63,6 \%)$ yang memiliki riwayat menderita penyakit jantung sebelumnya. 
Hasil penelitian ini serupa dengan penelitian yang dilakukan oleh Wiyati di Semarang, dimana mayoritas ibu hamil dengan penyakit memiliki riwayat menderita penyakit jantung sebelum hamil. Terdapat 33 kasus (55,9\%) ibu hamil yang mengalami riwayat menderita penyakit jantung sebelum kehamilan. ${ }^{9}$

Adanya riwayat menderita penyakit jantung sebelum kehamilan merupakan salah satu komponen dari The Cardiac Disease in Pregnancy (CARPREG) Risk Score. Terdapat 4 poin dalam sistem skor ini, dimana semakin banyak poin yang terpenuhi akan semakin besar kemungkinan munculnya komplikasi dalam kehamilan dengan penyakit jantung. Berikut kriteria The Cardiac Disease in Pregnancy (CARPREG) Risk Score :

riwayat gangguan jantung atau aritmia, NYHA $>$ II atau sianosis, obstruksi jantung kiri (katup mitral $<2 \mathrm{~cm}^{2}$. katup aorta ,1,5 $\mathrm{cm}^{2}$ atau gradient aliran keluar ventrikel kiri (LVOT ) > $30 \mathrm{mmHg}$, fraksi ejeksi ventrikel kiri $<40 \%$. Kemungkinan terjadinya komplikasi kardiovaskular jika 0 poin $=5 \%, 1$ poin $=$ $27 \%$ dan $>1$ poin $=75 \%$.

\section{Jumlah kunjungan antenatal}

Berdasarkan banyaknya kunjungan antenatal yang dilakukan selama kehamilan, mayoritas ibu (72,7\%) melakukan kunjungan antenatal sebanyak 4 kali atau lebih. Hal ini sejalan dengan penelitian oleh Wiyati di Semarang, dimana mayoritas (93,2\%) pasien hamil dengan penyakit jantung melakukan kunjungan antenatal sebanyak 4 kali atau lebih. ${ }^{9}$

Rekomendasi terbaru oleh WHO pada tahun 2016 menganjurkan setidaknya ibu hamil melakukan kunjungan antenatal sebanyak 8 kali selama kehamilan. Satu kali kunjungan sebelum usia kehamilan 12 minggu, dilanjutkan dengan 2 kali kunjungan selama trimester kedua dan 5 kali kunjungan selama trimester ketiga. Terdapat bukti bahwa angka kematian perinatal lebih rendah pada model 8 kali kunjungan antenatal. ${ }^{15}$ Indonesia sendiri sampai saat ini masih menerapkan anjuran kunjungan antenatal minimal sebanyak 4 kali selama kehamilan. Namun jumlah kunjungan ini dapat lebih banyak pada kehamilan dengan risiko tinggi, salah satunya kehamilan dengan penyakit penyulit seperti penyakit jantung. ${ }^{16}$

\section{Frekuensi komplikasi kehamilan dengan penyakit jantung}

Berdasarkan hasil penelitian didapatkan sebanyak 19 kehamilan (57,6\%) yang mengalami komplikasi. Frekuensi munculnya komplikasi pada kehamilan dengan penyakit jantung dalam penelitian ini lebih tinggi dibandingkan beberapa penelitian terdahulu. Hasil penelitian oleh Gelson et al terdapat 111 kasus (34\%) kehamilan dengan penyakit jantung yang disertai komplikasi pada bayi. ${ }^{8}$ Penelitian oleh Silversides et al menunjukkan terdapat 307 kasus $(15,8 \%)$ kehamilan dengan penyakit jantung, yang disertai dengan komplikasi pada ibu. ${ }^{17}$

\section{Gambaran komplikasi kematian maternal pada ibu hamil dengan penyakit jantung}

Tidak ditemukan munculnya komplikasi pada kehamilan dengan penyakit jantung berupa kematian maternal dalam penelitian ini. Penelitian Wiyati di Semarang menunjukkan bahwa terdapat 5 kasus (8,5\%) kematian maternal pada ibu hamil dengan penyakit jantung. ${ }^{9}$ Penelitian oleh Pandey et al menunjukkan bahwa dari 117 kasus kehamilan dengan penyakit jantung, terdapat 6 kasus (5,12\%) yang berakhir dengan kematian ibu. ${ }^{11}$

Penyakit jantung merupakan penyebab nonobstetrik utama kematian maternal akibat di negara maju maupun negara berkembang. ${ }^{18}$ Masalah utama kehamilan dengan penyakit jantung di negara berkembang adalah kurangnya deteksi dini sehingga penanganan yang dilakukan tidak adekuat dan meningkatkan risiko untuk terjadinya kematian maternal. Status sosial ekonomi yang rendah juga meningkatkan risiko kematian maternal akibat keterbatasan akses ibu hamil ke fasilitas pelayanan kesehatan. ${ }^{2,18}$ Indonesia telah menerapkan program "Safe Motherhood Initiative" yang terdiri atas 4 pilar utama yaitu keluarga berencana, asuhan antenatal, persalinan bersih dan aman, serta pelayanan obstetri esensial. Keempat pilar ini merupakan bentuk intervensi terhadap faktor utama kematian dan kesakitan ibu, yaitu kehamilan itu sendiri, persalinan, dan komplikasi persalinan. ${ }^{19}$ 


\section{Gambaran komplikasi gagal jantung pada ibu hamil dengan penyakit jantung}

Terdapat sebanyak 3 kasus (9,1\%) kehamilan dengan penyakit jantung yang mengalami komplikasi berupa gagal jantung. Angka ini lebih rendah dibandingkan dengan hasil penelitian Wiyati di Semarang, dimana terdapat 59 kasus yang disertai komplikasi gagal jantung. ${ }^{9}$ Penelitian oleh Owens et al menunjukkan terdapat sebanyak 278 kasus (7,2\%) yang disertai komplikasi gagal jantung. ${ }^{12}$

Kehamilan berhubungan dengan kondisi volume overload yang disertai dengan peningkatan cardiac output yang berbahaya pada trimester kedua dan ketiga, karena periode tersebut merupakan puncak dari peningkatan volume darah, cardiac output, dan denyut jantung. Pada penderita kelainan katup seperti stenosis katup aorta perubahan ini tidak dapat dikompensasi oleh jantung yang sebelumnya sudah mengalami hipertrofi konsentrik dan dilatasi ventrikel sehungga dapat meningkatkan risiko terjadinya gagal jantung. ${ }^{4,20}$

\section{Gambaran komplikasi aritmia pada ibu hamil dengan penyakit jantung}

Berdasarkan hasil penelitian, terdapat 8 kasus (24,2\%) kehamilan dengan penyakit jantung yang disertai munculnya komplikasi berupa aritmia. Hasil penelitian ini lebih tinggi dari penelitian oleh Wiyati di Semarang, dimana hanya terdapat 3 kasus (5,1\%) kehamilan dengan penyakit jantung yang disertai komplikasi aritmia. ${ }^{9}$ Penelitian oleh Owens et al menunjukkan terdapat sebanyak 278 kasus (7,2\%) kehamilan dengan penyakit jantung yang disertai komplikasi aritmia. $^{12}$

Selama kehamilan terjadi penurunan resistensi vaskular dan peningkatan volume darah sehingga menghasilkan stroke volume yang lebih tinggi. Berbagai perubahan ini akan dikompensasi oleh jantung berupa remodeling struktural jantung seperti penebalan massa ventrikel. Pada ibu dengan penyakit jantung, perubahan ini terkadang tidak dapat ditoleransi dengan baik oleh sistem konduksi jantung, dimana terjadi kekacauan irama jantung akibat perubahan struktural ini. ${ }^{21}$

\section{Gambaran komplikasi edema paru pada ibu hamil dengan penyakit jantung}

Terdapat sebanyak 5 kasus (15,2\%) kehamilan dengan penyakit jantung yang disertai dengan komplikasi berupa edema paru. Jumlah ini lebih rendah dari hasil penelitian Wiyati di RSUP dr. Kariadi Semarang, dimana didapatkan sebanyak 13 kasus (22\%) kehamilan dengan penyakit jantung yang disertai komplikasi edema paru. ${ }^{9}$ Penelitian oleh Silversides et al menunjukkan terdapat 106 kasus (5,5\%) kehamilan dengan penyakit jantung yang disertai komplikasi edema paru. ${ }^{17}$

Edema paru dalam kehamilan dengan penyakit jantung terjadi karena adanya imbalance tekanan hidrostatik kapiler, tekanan onkotik koloid, dan permeabilitas kapiler. Wanita hamil dengan penyakit jantung berisiko tinggi seperti stenosis katup mitral memiliki risiko untuk mengalami edema paru akibat ketidakseimbangan antara ketiga tekanan ini. ${ }^{22}$ Selama persalinan, autotransfusi darah dari sirkulasi uteroplasental ke sirkulasi ibu, terapi cairan yang berlebihan dan pemberian agen tokolitik seperti $\hat{a}-$ adrenoceptor antagonist dapat pula mencetuskan terjadinya edema paru. juga dapat menyebabkan edema paru. ${ }^{22,23}$

\section{Gambaran komplikasi kematian perinatal pada bayi dari ibu dengan penyakit jantung}

Tidak ditemukan adanya kematian perinatal pada bayi dari ibu dengan penyakit jantung yang menjadi sampel dalam penelitian ini. Penelitian Wiyati di Semarang menunjukkan bahwa terdapat sebanyak 5 kasus $(7,9 \%)$ kematian perinatal pada bayi dari ibu yang menderita penyakit jantung. ${ }^{9}$ Penelitian oleh Pandey et al menunjukkan terdapat sebanyak 9 kasus $(7,7 \%)$ kematian perinatal pada bayi dari ibu dengan penyakit jantung. ${ }^{11}$

Kematian perinatal merupakan komplikasi yang bersifat multifaktorial. Status kesehatan ibu yang buruk seperti menderita penyakit jantung, pelayanan antenatal yang tidak adekuat selama kehamilan, manajemen komplikasi yang tidak tepat selama kehamilan hingga persalinan, manajemen persalinan yang tidak higienis, dan perawatan neonatus yang tidak dilakukan dengan baik berperan dalam menyebabkan kematian perinatal. Selain itu status sosial ekonomi dan status nutrisi ibu selama 
kehamilan juga dapat mempengaruhi terjadinya kematian perinatal. ${ }^{12}$

\section{Gambaran komplikasi BBLR pada bayi dari ibu dengan penyakit jantung}

Berdasarkan hasil penelitian didapatkan sebanyak 5 kasus $(15,2 \%)$ bayi dengan berat badan lahir rendah yang dilahirkan oleh ibu yang menderita penyakit jantung. Jumlah ini lebih rendah jika dibandingkan dengan penelitian oleh Wiyati di Semarang, dimana terdapat 32 kasus (50,8\%) bayi yang lahir dengan berat badan kurang dari 2500 gram. ${ }^{9}$

Penelitian oleh Gelson et al menunjukkan bahwa insidensi komplikasi BBLR pada bayi dari ibu dengan penyakit jantung lebih tinggi dari populasi kontrol (25\% berbanding 11\%). Dalam penelitian tersebut juga didapatkan bahwa insidensi BBLR lebih sering ditemukan dalam kelompok ibu dengan cardiac output yang rendah dan ibu dengan penyakit jantung yang sianotik. ( $p$ value $<0,5$ ). Kelompok ibu dengan cardiac output yang rendah seperti stenosis mitral dan regurgitasi aorta, serta kelompok ibu dengan penyakit jantung yang sianotik seperti hipertensi pulmonal dan tetralogy of fallot yang tidak dikoreksi. Berdasarkan hasil penelitian tersebut, dapat disimpulkan bahwa cardiac output merupakan salah satu faktor utama yang mempengaruhi optimalnya tumbuh kembang janin. ${ }^{8}$

\section{Gambaran komplikasi kelahiran prematur pada bayi dari ibu dengan penyakit jantung}

Terdapat sebanyak 7 kasus (21,2\%) bayi dari ibu dengan penyakit jantung yang lahir secara prematur dalam penelitian ini. Hasil penelitian ini lebih rendah dari penelitian Wiyati di RSUP dr. Kariadi Semarang, dimana dalam penelitian tersebut terdapat 24 kasus $(38,1 \%)$ bayi dari ibu dengan penyakit jantung yang lahir prematur. ${ }^{9}$ Penelitian oleh Makino et al di Jepang, menunjukkan terdapat sebanyak 77 kasus (12,9\%) kelahiran prematur dari ibu dengan riwayat penyakit jantung. ${ }^{24}$

Kehamilan dengan penyakit jantung memberikan dampak yang buruk bagi ibu dan janin. Penyakit jantung sianotik ataupun penyakit jantung yang menyebabkan cardiac output yang rendah dapat menyebabkan gangguan sirkulasi uteroplasental sehingga berdampak pada proses maturitas janin yang terganggu. Jika kehamilan berlanjut dapat terjadi kelahiran prematur ataupun asfiksia pada bayi. Oleh karena itu, dapat disimpulkan bahwa sirkulasi uteroplasental yang adekuat selain berpengaruh terhadap tumbuh kembang, juga berpengaruh terhadap proses maturitas janin..$^{8,9}$

\section{SIMPULAN}

Insidensi kehamilan dengan penyakit jantung sebanyak 37 kasus dari 8.685 persalinan (0,43\%). Usia pasien hamil dengan penyakit jantung terbanyak pada rentang usia 20-35 tahun (72,7\%). Ibu hamil dengan penyakit jantung sebagian besar memiliki riwayat menderita penyakit jantung sebelum hamil (63,6\%). Terdapat 24 kasus (72,7\%) ibu hamil dengan penyakit jantung yang melakukan kunjungan antenatal lebih dari 4 kali selama kehamilan. Frekuensi kehamilan dengan penyakit jantung yang disertai komplikasi adalah sebanyak 19 kasus (57,6\%).

Komplikasi kehamilan dengan penyakit jantung yang ditemukan pada ibu adalah gagal jantung sebanyak 3 kasus (9,1\%), aritmia sebanyak 8 kasus (24,2\%), dan edema paru sebanyak 5 kasus (15,2\%). Tidak ditemukan munculnya komplikasi kematian maternal pada penelitian ini. Komplikasi kehamilan dengan penyakit jantung yang ditemukan pada bayi adalah bayi berat lahir rendah (BBLR) sebanyak 5 kasus (15,2\%) dan kelahiran prematur sebanyak 7 kasus (21,2\%). Tidak ditemukan munculnya komplikasi kematian perinatal pada penelitian ini.

\section{DAFTAR PUSTAKA}

1. Stangl V, Schad J, Gossing G, Borges A, Baumann G, Stangl K. Maternal heart disease and pregnancy outcome: a single-centre experience. Eur J Heart Fail. 2008;10(9):855-60.

2. Ashrafi R, Curtis SL. Heart disease and pregnancy. Cardiol Ther. 2017;6(2):157-59.

3. Say L, Chou D, Gemmil A, Tunçalp Ö, Moller AB, Daniels J, et al. Global causes of maternal death: a WHO systematic analysis. Lancet Glob Heal. 2014;2(6):323-33. 
4. Zagrosek VR, Hesselink JWR, Bauersachs J, Lundqvist CBL, Cifkova R, Bonis MD, et al. 2018 ESC guidelines on the management of cardiovascular diseases during pregnancy. Eur Heart J. 2018;39(34):3165-203.

5. MBRRACE-UK. Saving lives, improving mothers' care- lessons learned to inform maternity care from the UK and Ireland confidential enquiries into maternal deaths and morbidity 2013-15. [Internet]. 2017.

6. Kementerian Kesehatan RI. Mother's day [Internet]. Pusat Data dan Informasi Kementerian Kesehatan RI. 2014.

7. Dinas Kesehatan Provinsi Riau. Profil kesehatan Provinsi Riau 2015 [Internet]. 2015.

8. Gelson E, Johnson M. Effect of maternal heart disease on pregnancy outcomes. Expert Rev Obstet Gynecol. 2010;5(5):605-07.

9. Wiyati PS, Wibowo B. Luaran maternal dan perinatal pada hamil dengan penyakit jantung di RSUP Dr. Kariadi Semarang. Maj Obstet Ginekol. 2013;21(1):23-5.

10. Tanika RM. Insidensi dan karakteristik kehamilan dengan penyakit jantung di RSUD Arifin Achmad Provinsi Riau periode 2014-2016 [skripsi]. Pekanbaru: Fakultas Kedokteran Universitas Riau;2018.

11.Pandey K, Verma K, Gupta S, Jahan U, Kirti N, Gupta P. Study of pregnancy outcome in women with cardiac disease/ : a retrospective analysis. Int J Reprod Contraception, Obstet Gynecol. 2016;5(10):3537-41.

12. Owens A, Yang J, Nie L, Lima F, Avila C, Stergiopoulos K, et al. Neonatal and maternal outcomes in pregnant women with cardiac disease. J Am Hear Assoc. 2018;7(21):2-9.

13. Restrepo-Méndez MC, Lawlor DA, Horta BL, Matijasevich A, Santos IS, Menezes AMB, et al. The association of maternal age with birthweight and gestational age/ : a cross-cohort comparison. Paediactric Perinat Epidemiol. 2015;29(1):33-7.

14. Thanajiraprapa T, Phupong V. Pregnancy complications in women with heart disease. $\mathrm{J}$ Matern Neonatal Med. 2010;23(10):1201-3.
15. World Health Organization. New guidelines on antenatal care for a positive pregnancy experience [Internet]. November 2016. [cited 2018 November] Available from: https:// www.who.int/reproductivehealth/news/ antenatal-care/en/

16. Adriaansz G. Asuhan antenatal. In: Saifuddin AB, Rachimhadhi T, Wiknjosastro GH, editors. Ilmu Kebidanan Sarwono Prawirarohardjo. 4th Ed. Jakarta: PT Bina Pustaka Sarwono Prawirohardjo; 2016. p. 278-87.

17. Silversides CK, Grewal J, Mason J, Sermer M, Kiess M, Rychel V, et al. Pregnancy outcomes in women with heart disease. J Am Coll Cardiol. 2018;71(21):2419-30.

18. Mocumbi A, Sliwa K, Soma-Pillay P. Medical disease as a cause of maternal mortality: the preimminence of cardiovascular pathology. Cardiovasc J Afr. 2016;27(2):84-8.

19. Saifuddin AB. Kematian ibu dan perinatal. In: Saifuddin AB, Rachimhadhi T, Wiknjosastro GH, editors. Ilmu Kebidanan Sarwono Prawirohardjo. 4th Ed. Jakarta: PT Bina Pustaka Sarwono Prawirohardjo; 2016. p. 55-8.

20.Sedyawan JH. Penyakit jantung katup. In: Saifuddin AB, Rachimhadhi T, Wiknjosastro GH, editors. Ilmu Kebidanan Sarwono Prawirohardjo. 4th Ed. Jakarta: PT Bina Pustaka Sarwono Prawirohardjo; 2016. p. 767-71

21.Cordina R, McGuire M. Maternal cardiac arrhythmias during pregnancy and lactation. Obstet Med. 2010;3(1):8-16.

22.Dennis AT, Solnordal CB. Acute pulmonary oedema in pregnant women. Anaesthesia. 2012;67(6).

23. Anthony J, Sliwa K. Decompensated heart failure in pregnancy. Eur Cardiol. 2016;2(1):20-3.

24. Makino Y, Matsuda Y, Mitani M, Shinohara T, Matsui H. Risk factors associated with preterm delivery in women with cardiac diseases. J Cardiol. 2012;59(3):291-8 